\title{
\begin{tabular}{l|l|l} 
Jurnal Eksplorasi Akuntansi & e-ISSN : 2656-3649 (Online) \\
Vol. 3, No 1, Februari 2021, Hal 137-152 & http://jea.ppj.unp.ac.id/index.php/jea
\end{tabular}
}

\section{Pengaruh Reputasi Underwriter, Reputasi Auditor, dan Ukuran Perusahaan terhadap Underpricing Perusahaan yang Melakukan Initial Public Offering (IPO) di BEI}

\author{
Ary Syofian', Nurzi Sebrina ${ }^{2}$ \\ ${ }^{1,2}$ Jurusan Akuntansi Fakultas Ekonomi Universitas Negeri Padang \\ *Korespondensi: arysyofian.unp@gmail.com
}

\begin{abstract}
The purpose of this research is to examine the effect of underwriter's reputation, auditor reputation, and firm size on underpricing. This research is classified as causative research with a quantitative approach. The population are IPO companies listed on the Indonesia Stock Exchange period of 2014 to 2018. By using the purposive sampling method, there were 83 companies as the research's sample. The type of data used is secondary data obtained from the official site of the Indonesia Stock Exchange and the company's official website. The Hypothesis were tests using multiple linear regression analysis. The results indicate that the underwriter's reputation has a significant negative effect on underpricing level, and the auditor's reputation and firm size has not effect on underpricing.
\end{abstract}

Keywords: Underpricing; Underwriter's Reputation; Auditor's Reputation; Firm Size.

How to cite

Syofian, A., \& Nurzi, S. (2020). Pengaruh Reputasi Underwriter, Reputasi Auditor, dan Ukuran Perusahaan Terhadap Underpricing Perusahaan yang Melakukan Initial Public Offering (IPO) di BEI. Jurnal Eksplorasi Akuntansi, 3 (1), 137-152.

\section{PENDAHULUAN}

Dunia bisnis yang semakin kompetitif membuat kondisi pasar modal semakin berkembang. Hal ini dapat dilihat bahwa semakin banyak perusahaan yang terdaftar di Bursa Efek Indonesia. Kondisi tersebut membuat banyak perusahaan melakukan ekspansi dalam rangka mengembangkan usaha untuk memenuhi kebutuhan dana. Kebutuhan dana suatu perusahaan akan semakin meningkat seiring dengan pertumbuhan dan perkembangan perusahaan. Sehingga perusahaan tersebut diharuskan untuk memperoleh tambahan dana baru. Hal ini dapat dilakukan dengan menawarkan serta menjual saham perusahaan tersebut kepada masyarakat melalui bursa efek.

Initial public offering (IPO) merupakan kegiatan atau upaya dari emiten (perusahaan penerbit) menawarkan atau menjual saham perdana kepada calon investor. Hal yang terpenting dalam penawaran saham IPO adalah penetapan harga perdana. Calon emiten dihadapkan dengan tantangan dalam penetapan harga penawaran saham karena belum tersedianya harga yang relevan. Hal ini terjadi karena saham emiten tidak tersedia untuk publik sebelum melakukan IPO (Gumanti, 2002). Akibatnya, calon emiten tidak mempunyai informasi yang banyak dalam menilai harga IPO yang tepat. Tantangan tersebut perlu 
mendapatkan perhatian khusus. Jika tidak, emiten berpotensi untuk mendapatkan harga IPO dengan status underpricing.

Kondisi ketika harga IPO berada pada nilai lebih rendah dibanding nilai pada pasar sekunder pada saat IPO disebut underpricing (Ritter, 1998). Underpricing ini membuat emiten tidak dapat menyerap dana publik secara maksimal dari kegiatan IPO. Hal ini terjadi dari tindakan penetapan harga IPO yang tidak sesuai (Beatty, 1989). Fenomena underpricing hampir selalu terjadi dan mendominasi IPO pada bursa dimana saja (Aggarwal et al., 1994). Namun, hingga saat ini penyebab terjadinya underpricing masih belum mampu dijelaskan secara tepat.

Penerbitan prospektus dilakukan perusahaan untuk mengurangi adanya asimetri informasi yang berisi informasi dari perusahaan yang bersangkutan. Prospektus merupakan berkas data yang memuat kumpulan informasi mengenai nilai, kinerja, risiko, potensi masa depan yang akan menggambarkan kondisi perusahaan secara utuh. Berkas tersebut mengedukasi calon investor untuk dapat yakin mendapatkan saham yang ditawarkan dengan menunjukkan gambaran kualitas saham.

Faktor-faktor yang mempengaruhi underpricing dalam penelitian ini diantaranya reputasi underwriter (RUD), reputasi auditor (RAU), dan ukuran perusahaan (FSIZE). Underwriter merupakan penjamin emisi yang mempunyai kelengkapan informasi terhadap permintaan saham-saham yang ditawarkan emiten. Reputasi yang dimiliki underwriter diharapkan mampu memberikan pertimbangan tepat dalam mengambil keputusan mengenai harga penawaran supaya tidak lebih rendah setelah listing pada pasar sekunder menghindari terjadinya underpricing (Tatang et.al, 2015). Auditor merupakan pihak independen yang memberikan integritas dan indepedensinya dalam mengaudit laporan keuangan dan memberikan opini publik terhadap pelaporan perusahaan. Auditor akan menfiltrasi atau menghambat upaya emiten dalam melakukan kecurangan dalam memberi informasi perusahaan terhadap publik. Kehadiran auditor yang bereputasi diharapkan mampu menekan tingkat underpricing saham pada saat IPO. Ukuran perusahaan menjadi faktor ketidakpastian saham. Perusahaan dengan skala lebih besar dinilai lebih mudah memperoleh investor dibandingkan perusahaan dalam kriteria skala kecil. Skala perusahaan dilihat dari nilai total aset pada laporan keuangan perusahaan sebelum melakukan IPO. Investor akan dihadapkan dengan pilihan mengambil risiko ketidakpastian saham dengan jumlah informasi yang diterimanya (Ardiansyah, 2004).

Beberapa penelitian sebelumnya yang membahas mengenai underpricing tidak menunjukkan hasil yang konsisten. Penelitian Ayuwardani (2018), Nadia dan Daud (2017) serta Fadila et al. (2015), menunjukkan berpengaruh signifikan secara negatif antara reputasi underwriter dan tingkat underpricing. Sedangkan pada penelititian Wicaksono (2012) menunjukkan reputasi underwriter secara signifikan tidak memiliki pengaruh dengan underpricing. Penelitian lain yang menunjukkan hasil tidak konsisten juga ditemukan pada variabel reputasi auditor (RAU). Pada penelitian Indra Arifin Djashan (2017) menunjukkan adanya pengaruh negatif reputasi auditor terhadap underpricing. Namun penelitian Saifudin (2016) menunjukkan bahwa reputasi auditor tidak berpengaruh terhadap underpricing. Ukuran Perusahaan (FSIZE) juga merupakan faktor yang dapat mempengaruhi underpricing. Beberapa penelitian telah dilakukan mengenai pengaruh ukuran perusahaan terhadap underpricing dan menunjukan hasil yang juga tidak konsisten. Pada peneliatian Hapsari dan Mahfud (2012) Ukuran Perusahaan (FSIZE) berpengaruh terhadap underpricing. sedangkan pada penelitian Purbarangga dan Yuyetta (2013) Ukuran Perusahaan (FSIZE) tidak berpengaruh terhadap underpricing.

Berdasarkan latar belakang dan hasil riset terdahulu yang tidak konsisten maka penelitian ini dilakukan untuk memperoleh bukti empiris mengenai "Pengaruh Reputasi Underwriter, Reputasi Auditor, Dan Ukuran Perusahaan Terhadap Underpricing 
Perusahaan Yang Melakukan Initial Public Offering (IPO) Studi Empiris Pada Perusahaan yang Terdaftar Di BEI Periode 2014-2018"

\section{REVIU LITERATUR DAN HIPOTESIS \\ Asymmetry Theory}

Asimetri informasi menjadi teori perbedaan informasi yang dimiliki stakeholder sebagai agent dan principal dalam pembentukan harga saham perdana (IPO). Perbedaan ini mengakibatkan perbedaan kelengkapan informasi yang dimiliki oleh agent dibandingkan dengan principal. Asimetri informasi membuat principal tidak sepenuhnya dapat mengetahui dan memprediksi kinerja perusahaan emiten yang dikelola oleh agent (Kaplan dan Alkinson, 1998).

Keadaan asimetri informasi dinilai mengecewakan principal karena mereka tidak mendapatkan informasi yang sesuai dengan keadaan emiten yang sebenarnya walaupun mereka telah berinvestasi. Keadaan perbedaan tersebut bisa menjadi celah bagi pengelola/agent melakukan tindakan kecurangan terhadap kesepakatan awal bersama principal. Tidak selarasnya tujuan antara agent dan principal akan memicu terjadinya konflik yang memprioritaskan keinginan masing-masing. Terdapat tiga asumsi dasar dari sifat manusia yaitu egosentris, prediksi masa depan, dan kecendrungan risk averse (Eisenhardt, 1989). Berdasarkan teori ini membuat berbagai informasi yang diberikan untuk orang lain perlu dipertanyakan dan diperdalam. Akibat dari berkembangnya teori asimetri informasi yaitu adanya moral hazard dan adverse section (Scott, 2000).

\section{Penawaran Saham Perdana (Initial Public Offering)}

Initial public offering (IPO) merupakan kegiatan atau upaya dari emiten (perusahaan penerbit) menawarkan atau menjual saham perdana kepada calon investor. Emiten yang menawarkan saham pertama kali atau saham IPO harus sudah listing ke dalam pasar modal. Tujuan emiten melakukan IPO adalah untuk mendapatkan suntikan pendanaan murah, meningkatkan kinerja keuangan perusahaan agar lebih baik, meningkatkan prospek pertumbuhan perusahaan, dan meningkatkan nilai perusahaan. Investor sebagai pemilik modal juga sangat berharap agar investasi yang dilakukan dapat berdampak pada kemajuan perusahaan (Putra et al., 2021)

\section{Underpricing}

Keadaan Underpricing saham terjadi ketika harga penawaran saham dipasar primer lebih rendah dibandingkan dengan harga saham pada saat listing di pasar sekunder. Underpricing saham menjadi keadaan yang tidak menguntungkan bagi emiten saat saham dijual dibawah nilai pasar yang seharusnya yang berakibat emiten tidak dapat menyerap dana publik secara optimal (Brigham, 2001). Perbedaan rentang harga antara pasar primer dengan sekunder disebut dengan Initial Return (IR) (Jogiyanto, 2012).

Harga IPO yang diterbitkan merupakan perhitungan dan perencanaan yang dilakukan oleh penjamin emisi bersama dengan emiten. Penjamin emisi mengambil pertimbangan atas nilai saham yang akan ditawarkan melalui besaran kekuatan penawaran dan besaran jumlah permintaan investor. Perhitungan besaran nilai initial return dinilai dari jumlah selisih harga saat pasar primer dengan pasar sekunder. Saham berada pada keadaan underpricing ketika harga saham pada pasar primer jauh lebih rendah dibanding harga pada pasar sekunder di hari pertama (Azizi Nur Wicaksono, 2012).

\section{Reputasi Underwriter}

Pasal Nomor 17 UU Nomor 8 Tahun 1995 tentang Pasar Modal menyatakan defenisi underwriter adalah penjamin emisi sebagai pihak pembuat kontrak dengan perusahaan emiten penerbit saham IPO dengan catatan khusus dibebankan membeli saham tak laku ataupun 
tanpa beban. Kontribusi underwriter selaku perantara kepentingan emiten dalam menyerap dana publik dengan investor selaku pemodal.

Penelitian Triningsih (2005) menunjukkan emiten yang bekerjasama dengan underwriter yang mempunyai kapabilitas atau reputasi diharapkan mampu memberikan informasi yang belum terungkap dalam preediksi prospektus. Underwriter akan mencoba memberikan transparansi informasi mengenai kondisi internal atau prospek emiten agar investor dapat tertarik untuk mendapatkan saham dan tidak tersesat dengan informasi yang beredar. Underwriter dengan tingkat kapabilitas rendah cenderung untuk tidak mengambil risiko apabila pada saat listing di pasar sekunder saham yang ditawarkan tidak diminati dan tidak terjual (Yasa, 2008). Emiten yang menggunakan penjamin emisi mempunyai kapabilitas tinggi akan mengurangi tingkat risiko emiten dan mengurangi initial return bagi investor.

\section{Reputasi Auditor}

Syarat untuk go public bagi emiten salah satunya adalah kondisi kinerja keuangan perusahaan yang layak (feasible) (Fahmi, 2012:7). Perusahaan dengan kondisi baik dibuktikan dengan laporan keuangan perusahaan yang baik dan sesuai dengan standar akuntansi berlaku. Laporan keuangan yang baik dapat teruji kebenarannya oleh profesi auditor. Auditor yang mempunyai kapabilitas akan memeriksa laporan keuangan perusahaan dengan menerapkan prinsip indepedensi. Auditor juga akan megkoreksi laporan keuangan apabila terdapat kekeliruan dan ketidak sesuaian dengan PSAK yang berlaku. Akhir dari proses pemeriksaan yang dilakukan oleh auditor adalah dalam bentuk pemberian opini kepada publik apakah perusahaan telah menyajikan laporan keuangan secara wajar atau belum. Investor akan mengukur dan menilai kelayakan perusahaan tersebut untuk mendapatkan pendanaan dari mereka.

Auditor yang bereputasi akan menjunjung tinggi kode etik auditor. Kode etik tersebut adalah integritas, obyektifitas, kerahasiaan, kompetensi, akuntabel, dan profesionalisme. Auditor yang memegang kode etik auditor dalam memeriksa setiap laporan keuangan perusahaan akan berpegang teguh pada kualitas hasil audit. Hal ini ditujukan agar laporan keuangan yang telah di audit dapat menjadi pedoman bagi investor serta memberikan keyakinan untuk berinvestasi (Helen, 2005). Auditor yang bereputasi secara langsung berkontribusi menurunkan risiko ketidakpastian dan risiko terjadinya underpricing.

\section{Ukuran Perusahaan}

Ketidakpastian saham dapat dianalisa berdasarkan ukuran dari perusahaan emiten. Perusahaan dengan skala lebih besar dinilai lebih mudah memperoleh investor dibandingkan perusahaan dalam kriteria skala kecil. Investor akan dihadapkan dengan pilihan mengambil risiko ketidakpastian saham dengan jumlah informasi yang diterimanya (Ardiansyah, 2004). Perusahaan dengan prospek masa depan lebih baik akan lebih menarik bagi investor karena dianggap mampu meberikan keuntungan yang stabil (Syofyan \& Putra, 2020)

Perusahaan dengan skala lebih besar dinilai memiliki tingkat ketidakpastian lebih rendah. Ketidakpastian tersebut dilihat dari pengaruh yang diberikan perusahaan tersebut di pasar. Kondisi tersebut menunjukkan risiko investasi lebih kecil. Berbeda dengan perusahaan dengan skala lebih kecil, risiko ketidakpastian cenderung lebih besar yang berpengaruh langsung terhadap risiko investasi yang juga lebih besar. Berbagai faktor sebagai dasar pengukuran suatu perusahaan. Diantaranya yang paling dominan adalah besaran nilai aset. Nilai total aset dilihat dari nilai asset pada laporan keuangan perusahaan sebelum melakukan IPO. 


\section{Penelitian Terdahulu}

Penelitian terdahulu yang meneliti tentang underpricing dipengaruhi oleh reputasi underwriter, reputasi auditor dan ukuran perusahaan adalah penelitian yang dilakukan oleh Indra Arifin Djashan (2017), Natalia Titik Wijaya (2016), Rizky Riyadi (2015), Reza Widhar Pahlevi (2014), Eka Retnowati (2013) dengan ringkasan hasil penelitian sebagai berikut:

a. Reputasi underwriter tidak berpengaruh terhadap underpricing (Reza Widhar Pahlevi, 2014).

b. Reputasi underwriter memiliki hubungan negatif dengan underpricing (Indra Arifin Djashan, 2017; Saifudin, 2016; Rizky Riyadi, 2015).

c. Reputasi auditor tidak berpengaruh terhadap underpricing (Saifudin, 2016; Reza Widhar Pahlevi, 2014; Rizky Riyadi, 2015).

d. Reputasi auditor memiliki hubungan negatif dengan underpricing (Indra Arifin Djashan, 2017).

e. Ukuran perusahaan tidak berpengaruh terhadap underpricing (Saifudin, 2016; Rizky Riyadi, 2015).

f. Ukuran perusahaan memiliki hubungan negatif dengan underpricing (Natalia Titik Wijaya, 2016; Eka Retnowati, 2013).

\section{Pengembangan Hipotesis}

\section{Pengaruh Reputasi Underwriter Terhadap Underpricing}

Underwriter yang bereputasi diharapkan mampu memberikan informasi lebih meyakinkan investor untuk dapat memilih investasi yang tepat. Informasi yang meyakinkan terwujud dari nilai harga penawaran saham yang tepat dan meningkatkan kepercayaan investor dalam jangka panjang (Tatang et.al,2015). Underwriter sebagai penjamin emisi sangat berperan dalam pengambilan keputusan besaran harga penawaran saham bersama dengan emiten. Harga yang ditentukan melalui kesepakatan emiten dan underwriter sebagai penjamin emisi akan memberikan kabar baik kepada investor dengan tidak menetapkan harga saham rendah hanya untuk menarik investor. Ayuwardani (2018), Nadia dan Daud (2017) serta Fadila et al.(2015), menunjukkan berpengaruh signifikan secara negatif antara reputasi underwriter terhadap tingkat underpricing. Hal ini menunjukkan bahwa reputasi underwriter yang baik akan dapat meminimalkan risiko underpricing.

H1: Reputasi underwriter berpengaruh negatif terhadap underpricing.

\section{Pengaruh Reputasi Auditor Terhadap Underpricing}

Auditor berkualitas dipercaya mampu berkontribusi menurunkan tingkat underpricing. Kode etik auditor yang dipegang teguh dalam memeriksa laporan keuangan perusahaan emiten secara langsung akan menujukkan indepedensi. Seperti underwriter, auditor akan membawa kabar baik untuk calon investor serta memberi keyakinan untuk harga penawaran yang ditetapkan. Auditor bereputasi akan selalu bersikap profesional untuk dapat meyakinkan investor memilih investasi yang tepat. Indra Arifin Djashan (2017) juga menyatakan dalam penelitiannya bahwa variabel reputasi auditor berpengaruh secara negatif signifikan terhadap tingkat underpricing.

H2: Reputasi auditor berpengaruh negatif terhadap underpricing.

\section{Pengaruh Ukuran Perusahaan Terhadap Underpricing}

Nilai ukuran perusahaan akan menunjukkan skala perusahaan di mata investor. Ukuran ini akan diukur melalui besaran kekayaan, nilai aset, dan nilai buku emiten. Umumnya, perusahaan dengan nilai standar atau dibawah rata-rata perusahaan besar tidak begitu dikenal oleh masyarakat. Tingkat ketidakpastian perusahaan dimasa mendatang dapat diketahui diketahui dengan seberapa banyak informasi yang diketahui calon investor. Skala perusahaan 
diyakini memiliki pengaruh kuat terhadap tingkat underpricing perusahaan. Hapsari dan Mahfud (2012) menunjukkan hasil bahwa ukuran perusahaan berpengaruh negatif terhadap tingkat underpricing.

H3: Ukuran perusahaan berpengaruh negatif terhadap underpricing.

\section{METODE PENELITIAN}

Jenis Penelitian dan Sampel

Jenis penelitian ini adalah asosiatif kausal dengan pendekatan kuantitatif. Populasi penelitian ini adalah keseluruhan perusahahaan melakukan IPO di Indonesia dari tahun 20142018, yaitu sebanyak 144 perusahaan. Teknik pengambilan sampel penelitian ini menggunakan teknik purposive sampling. Kriteria tersebut telah dirangkum sebagai berikut :

Tabel 1

\section{Kriteria Pengambilan Sampel}

\begin{tabular}{lc}
\hline \multicolumn{1}{c}{ Keterangan } & Jumlah \\
\hline $\begin{array}{l}\text { Perusahaan yang pada tahun 2014-2018 melakukan } \\
\text { Initial public offering (IPO) di Indonesia. }\end{array}$ & 144 \\
$\begin{array}{l}\text { Perusahaan yang mengalami overpricing dan tidak } \\
\text { mengalami perubahan harga saham pada saat IPO pada }\end{array}$ & $(13)$ \\
tahun 2014-2018 & \\
Perusahaan keuangan yang melakukan IPO di Bursa & $(17)$ \\
Efek Indonesia pada tahun 2014-2018 & \\
$\begin{array}{l}\text { Perusahaan yang relisting selama tahun 2014-2018 } \\
\text { Laporan keuangan tidak lengkap }\end{array}$ & $(3)$ \\
Laporan keuangan menggunakan mata uang selain \\
rupiah
\end{tabular}

Berdasarkan kriteria tersebut, sampel yang menjadi fokus penelitian adalah sebanyak 83 perusahaan untuk 5 tahun pengamatan di mulai tahun 2014-2018.

\section{Sumber dan Teknik Pengumpulan Data}

Penelitian ini melihat laporan tahunan perusahaan sampel menggunakan teknik dokumentasi. Penggunaan teknik dokumentasi akan memberikan data langsung bagi peneliti sesuai penelitian yang dilakukan. Data tersebut diperoleh melalui situs resmi BEI www.idx.co.id, www.yahoofinance.com, dan sumber lain yang mendukung.

\section{Variabel Penelitian dan Pengukuran Underpricing}

Penilaian tingkat underpricing suatu perusahaan dapat dilihat dari kenaikan harga saham perusahaan ketika hari pertama masuk ke pasar sekunder. Proksi untuk mengukur tingkat underpricing dalam penelitian ini menggunakan proksi market-adjusted abnormal return (MAAR) yang digunakan dalam penelitian Aggarwal, Leal, dan Hernandez (1993). Perhitungan menggunakan metode MAAR dinilai lebih objektif dalam mengukur tingkat underpricing. Perhitungan mengenai tingkat underpricing saham adalah sebagai berikut:

$$
A R_{i t}=\left[\frac{\left(1+R_{i t}\right)}{\left(1+R_{m t}\right)}-1\right] \times 100
$$


Dimana MAAR ( $\left.\mathrm{AR}_{\mathrm{it}}\right)$ adalah Market-adjusted abnormal return, $\mathrm{R}_{\mathrm{it}}$ adalah Imbal hasil saham pada hari pertama (dalam persen), $\mathrm{R}_{\mathrm{mt}}$ adalah Imbal hasil pasar pada hari pertama dicatatkannya saham di Bursa Efek Indonesia

\section{Reputasi Underwriter}

Variabel independen dalam penelitian ini adalah reputasi underwriter. Reputasi underwriter merupakan penilaian kepada seorang underwriter atas kapabilitasnya dalam menjamin emisi saham perdana. Penilaian reputasi ini diukur berdasarkan ranking underwriter. Peneliti menggunakan variabel dummy untuk mengukur ranking underwriter yang tercatat sebagai 10 terbesar dengan nilai 1 dan diluar 10 besar dengan nilai 0 . Underwriter dengan reputasi baik rangking 10 besar telah tercatat dan terpublikasi pada 20 most active brokerage house atas ranking total frekuensi perdagangan. Pengukuran ini digunakan oleh peneliti Risqi dan Harto (2013).

\section{Reputasi Auditor}

Auditor bereputasi dipercaya mampu berkontribusi menurunkan tingkat underpricing. Kode etik auditor yang dipegang teguh dalam memeriksa laporan keuangan perusahaan emiten secara langsung akan menujukkan indepedensi. Hal ini ditunjukan agar laporan keuangan yang telah di audit dapat menjadi pedoman bagi investor serta memberikan keyakinan untuk berinvestasi (Helen, 2005). Peneliti menggunakan variabel dummy sebagai alat ukur reputasi auditor. Auditor dalam KAP yang telah berpartner dengan the Big Four akan mendapatkan nilai 1 dan yang tidak berpartner dengan the Big Four akan mendapatkan nilai 0 (Sulistio, 2005).

\section{Ukuran Perusahaan}

Ukuran perusahaan dapat dilihat dari jumlah total aset yang dimiliki perusahaan. Semakin besar aset perusahaan akan mengindikasi semakin besar ukuran perusahaan tersebut. Perusahaan dengan skala ekonomi yang lebih tinggi dan lebih besar dianggap mampu bertahan dalam waktu yang lama. Pengukuran ukuran perusahaan menggunakan logaritma natural aset perusahaan. Hal ini karena jika menggunakan nilai nyata asset maka data tidak berasumsi normal. Maka peneliti mengambil nilai logaritma natural dari nilai asset. Pengukuran menggunakan aset dinilai tepat dibanding nilai penjualan. Hal ini disebabkan nilai aset dinilai lebih normal dari nilai penjualan. Nilai asset secara langsung akan menunjukkan tingkat kepemilikan kekayaan perusahaan (Titman dan Wessels, 1988).

\section{FSIZE $=$ Ln (Total Aset)}

Dimana FSIZE merupakan nilai ukuran perusahaan, Ln merupakan logaritma natural, dan Total Aset adalah nilai kekayaan perusaan pada tahun penelitian.

\section{Teknik Analisis Data}

\section{Statistik Deskriptif}

Statistik deskriptif digunakan dalam mengolah, menyajikan, serta analisis data angka secara deskriptif. Statistik deskriptif secara khusus digunakan dalam menunjukkan jumlah data, nilai tertinggi dan terendah, nilai average serta nilai deviasi standar variabel penelitian (Ghozali, 2016).

\section{Analisis Induktif}

Metode yang digunakan dalam penelitian ini untuk menguji hipotesis penelitian adalah model regresi data cross section. Model regresi data panel merupakan model yang melibatkan 
lebih dari satu variabel bebas (independen) dan terdiri dari beberapa tahun pengamatan. Pengujian hipotesis dilakukan dengan regresi linier berganda (multiple regression analysis model). Alat analisis yang peneliti gunakan adalah Program Eviews. Peneliti menggunakan model persamaan regresi linier berganda dengan Ordinary Least Square atau persamaan kuadrat terkecil sebagai berikut:

$$
\mathrm{UP}=\alpha+\beta_{1} \mathrm{RUD}+\beta_{2} \mathrm{RAU}+\beta_{3} \text { FSIZE }+\varepsilon
$$

Keterangan

UP adalah tingkat underpricing, $\alpha$ adalah koefisien konstanta,

$\beta$ adalah Koefisien regresi dari tiap-tiap variabel independen,

RUD adalah reputasi underwriter,

RAU adalah reputasi auditor, FSIZE adalah ukuran perusahaan, dan $\varepsilon$ adalah nilai error.

Penguji melakukan uji asumsi klasik untuk meyakinkan peneliti atas kelayakan metode regresi yang peneliti digunakan dalam penelitian ini. Setelah pengujian dilakukan, peneliti dapat memperoleh keyakinan bahwa model yang digunakan tidak terdapat multikolinearitas dan heteroskedestisitas. Peneliti juga dapat memastikan bahwa data penelitian yang dihasilkan berdistribusi normal (Ghozali, 2016). Uji Model dilakukan dengan Uji F dan Uji Koefisien Determinasi, serta uji hipotesis dilakukan dengan Uji-t.

\section{HASIL DAN PEMBAHASAN}

\section{HASIL}

\section{Statistik Deskriptif} berikut:

Hasil analisis deskriptif variabel yang digunakan pada penelitian ini adalah sebagai

Tabel 2

Statistik Deskriptif

\begin{tabular}{lcccc}
\hline & UP & RUD & RAU & FSIZE \\
\hline Mean & 522.9444 & 0.216867 & 0.048193 & 27.50554 \\
Median & 503.7390 & 0.000000 & 0.000000 & 27.81000 \\
Maximum & 971.4510 & 1.000000 & 1.000000 & 31.66000 \\
Minimum & 88.05300 & 0.000000 & 0.000000 & 20.81000 \\
Std. Dev. & 256.0247 & 0.414617 & 0.215475 & 1.549217 \\
\hline
\end{tabular}

(Sumber: Data Olahan E-views9, 2020)

Berdasarkan tabel 2 di atas, variabel UP (underpricing) sebagai variabel dependen (UP) pada tahun 2014-2018 memiliki rata-rata sebesar 522.9444 dengan standar deviasi 256.0247. Nilai UP maksimum sebesar 971.4510 dan nilai minimum sebesar 88.053. Variabel reputasi underwriter sebagai variabel independen (RUD) pada IPO tahun 2014-2018 memiliki rata-rata sebesar 0.21686 . Variabel reputasi auditor sebagai variabel independen (RAU) pada IPO tahun 2014-2018 memiliki rata-rata sebesar 0.048193. Variabel ukuran perusahaan (FSIZE) pada IPO tahun 2014-2018 memiliki rata-rata sebesar 27.50554. Nilai maksimum sebesar 31.66000 dan nilai minimum sebesar 20.81000 . 


\section{Analisis Induktif}

Tabel 3

Regresi Linear Berganda

\begin{tabular}{|c|c|c|c|c|}
\hline & Prediksi & Coef & t-Stat & Prob \\
\hline $\mathrm{C}$ & - & 1200.475 & 2.569207 & 0.0121 \\
\hline RUD & Negatif & -199.8884 & -3.008320 & $(* *) \quad 0.0035$ \\
\hline RAU & Negatif & -172.5510 & -1.374646 & 0.1731 \\
\hline FSIZE & Negatif & -22.75418 & -1.333957 & 0.1861 \\
\hline
\end{tabular}

\begin{tabular}{cc} 
R-squared & 0.193198 \\
Adjusted R-squared & 0.162560 \\
Prob (F-statistic) & 0.000686 \\
\hline (Sumber: Data Olahan Eviews9 Tahun 2020) \\
(**) Prob $<0.05$ (Berpengaruh Signifikan)
\end{tabular}

Uji Model

Koefisien Determinan (adjusted $R$ - squared)

Berdasarkan hasil regresi pada tabel 3, nilai adjusted $R$-Square sebesar $16 \%$. Hal ini mengindikasikan bahwa kontribusi variabel independen terhadap variabel dependen sebesar $16 \%$ dan sebesar $84 \%$ ditentukan oleh variabel lain yang tidak dianalisis dalam model penelitian ini.

\section{Uji Signifikan Simultan (Uji F)}

Berdasarkan tabel 3 diketahui bahwa probabilitas (F-Statistic) $<0.05=0.000686<0.05$. Hal ini menandakan bahwa nilai probabilitas F-statistik lebih kecil dari nilai $\alpha=0.05$ artinya model regresi diterima atau model regresi ini menunjukkan tingkatan yang baik dimana variabel independen pada penelitian ini secara simultan berpengaruh terhadap variabel dependen (good overall model fit). Model regresi dapat digunakan mengukur pengaruh variabel independen penelitian terhadap underpricing saham IPO.

\section{Uji Normalitas dan Asumsi Klasik}

\section{Uji Normalitas}

Dari gambar 1 dibawah dapat dilihat bahwa residual data terdistribusi normal dimana nilai probabilitasnya $>$ a $(0,05)$ yaitu $0.236712>0,05$.

Gambar 1

Hasil Uji Normalitas

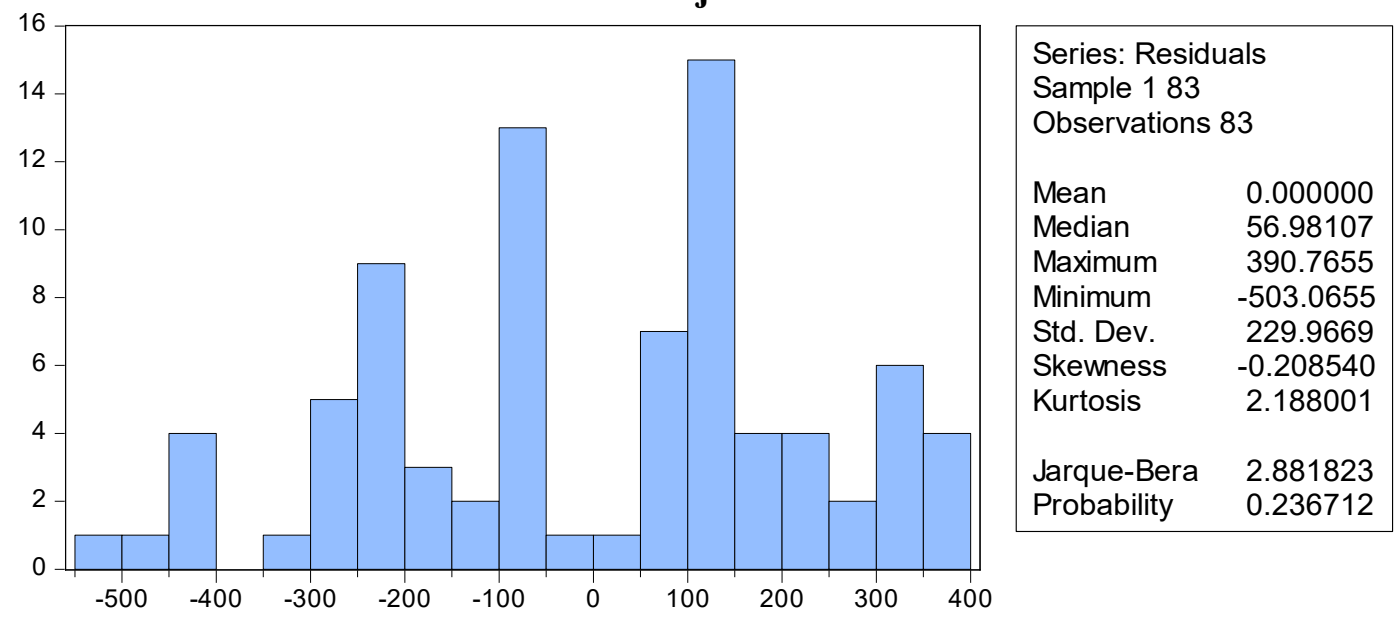

Sumber: Data Olahan Eviews9 Tahun 2020) 


\section{Uji Multikolinieritas}

Teknik pengujian multikolinearitas pada model regresi menggunakan metode VIF (Variance Inflation Factor). VIF menggambarkan kenaikan varians dari dugaan parameter antar peubah penjelas. Model regresi yang dinyatakan bebas dari multikolinieritas apabila nilai VIF $<10$. Hasil Uji multikolinieritas dapat dilihat pada tabel kolom Centered VIF. Nilai VIF untuk variabel RUD sebesar 1.133751, nilai variabel RAU adalah 1.092810 dan nilai VIF untuk variabel FSIZE sebesar 1.043181. Karena nilai VIF dari ketiga variabel tersebut tidak ada yang lebih besar dari 10, maka dapat dikatakan tidak terjadi multikolinieritas pada ketiga variabel bebas tersebut.

\section{Tabel 4}

Hasil Uji Multikolinearitas

\begin{tabular}{cccc}
\hline Variable & $\begin{array}{c}\text { Coefficient } \\
\text { Variance }\end{array}$ & $\begin{array}{c}\text { Uncentered } \\
\text { VIF }\end{array}$ & $\begin{array}{c}\text { Centered } \\
\text { VIF }\end{array}$ \\
\hline C & 218327.5 & 330.1180 & NA \\
RUD & 4414.963 & 1.447712 & 1.133751 \\
RAU & 15756.26 & 1.148143 & 1.092810 \\
FSIZE & 290.9636 & 333.8865 & 1.043181 \\
\hline (Sumber: Data Olahan Eviews9 Tahun 2020) & &
\end{tabular}

\section{Uji Heteroskedastisitas}

Mendeteksi adanya heteroskedastisitas digunakan uji White. Apabila nilai probabilitas ChiSquare dari Obs*R-Square $>$ a (0.05) maka tidak terdapat gejala heteroskedastisitas. Berdasarkan tabel 5 dibawah, probabilitas Chi-Square dari Obs*R-Square adalah 0.116409 yang $>0.05$ yang menunjukkan tidak ada gejala heteroskedastisitas.

Tabel 5

Hasil Uji Heteroskedastisitas

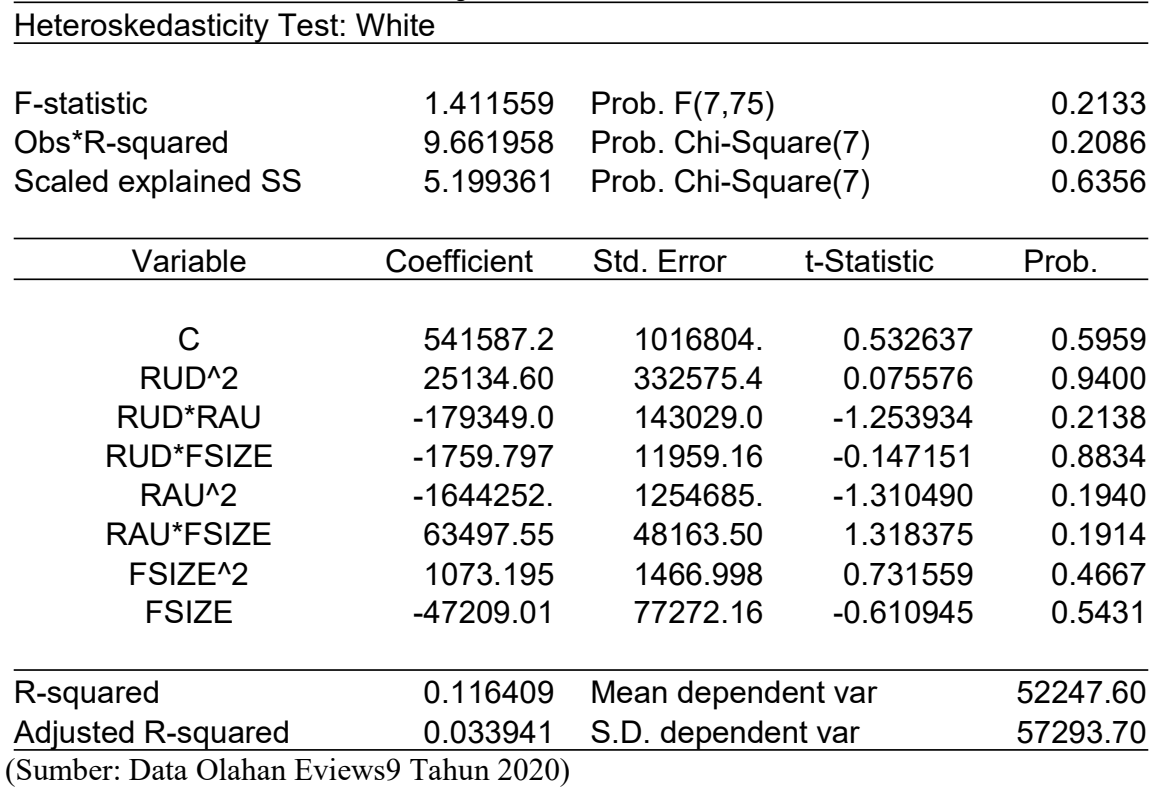

\section{Pengujian Hipotesis (Uji-t)}

Hipotesis pertama pada model regresi yang digunakan untuk mengestimasi pengaruh reputasi underwriter menekan tingkat underpricing. Berdasarkan tabel 3 diketahui bahwa probabilitas RUD bernilai 0.0035 dan besar koefisien adalah -199.8884 dengan t hitung 3.008320 , dan signifikan pada $\alpha 0.05$. Hal ini berarti reputasi underwriter berpengaruh 
negatif terhadap underpricing saham IPO dan signifikan karena $t$ hitung $>\mathrm{t}$ tabel yaitu $3.008320>1.66365$. Dengan demikian hipotesis pertama (H1) diterima. Pada hipotesis kedua pada model regresi yang digunakan untuk mengestimasi pengaruh reputasi auditor menekan tingkat underpricing.

Berdasarkan tabel 3 diketahui bahwa probabilitas RAU bernilai 0.1731 dan besar koefisien adalah -172.5510 dengan t hitung -1.374646 , dan tidak signifikan pada $\alpha 0.05$. Hal ini berarti reputasi auditor tidak berpengaruh terhadap underpricing saham IPO dan tidak signifikan karena t hitung $<\mathrm{t}$ tabel yaitu $-1.374460<1.66365$. Dengan demikian hipotesis

kedua (H2) ditolak. Sedangkan hipotesis ketiga pada model regresi yang digunakan untuk mengestimasi pengaruh ukuran perusahaan menekan tingkat underpricing. Berdasarkan tabel 3 diketahui bahwa probabilitas FSIZE bernilai 0.1861 dan besar koefisien adalah -22.75418 dengan t hitung -1.333957, dan tidak signifikan pada $\alpha 0.05$. Hal ini berarti ukuran perusahaan tidak berpengaruh terhadap Underpricing saham IPO dan tidak signifikan karena t hitung $<$ t tabel yaitu $-1.367046<1.66365$. Dengan demikian hipotesis ketiga (H3) ditolak.

\section{PEMBAHASAN}

\section{Pengaruh Reputasi Underwriter Terhadap Underpricing}

Hipotesis pertama pada penelitian ini adalah reputasi underwriter berpengaruh negatif terhadap underpricing saham saat IPO. Semakin bereputasi underwriter dalam menjamin emiten saat IPO maka semakin rendah tingkat underpricing. Berdasarkan hasil penelitian, diketahui reputasi underwriter berpengaruh dengan nilai koefisien bernilai negative sebesar 199.8884 nilai probabilitas sebesar 0.0035 dan signifikan pada $\alpha 5 \%$. Hal ini berarti reputasi underwriter berkontribusi negatif dan berpengaruh signifikan terhadap underpricing, karena nilai prob $<0,05$, yaitu $0.0035>0,05$. Hal tersebut menunjukkan bahwa semakin bereputasi underwriter maka akan berpengaruh terhadap tingkat underpricing saham saat IPO. Hasil penelitian ini sesuai dengan penelitian oleh Ayuwardani (2018), Nadia dan Daud (2017) dan Wicaksono (2012) menguji pengaruh variabel reputasi underwriter terahadap underpricing. Hasil penelitian Ayuwardani (2018), Nadia dan Daud (2017) serta Fadila et al.(2015), menunjukkan berpengaruh signifikan secara negatif antara reputasi underwriter dan tingkat underpricing. Hal ini menunjukkan bahwa reputasi underwriter yang baik akan dapat meminimalkan risiko underpricing. Namun, penelitian Wicaksono (2012) menunjukkan reputasi underwriter secara signifikan tidak memiliki pengaruh dengan underpricing.

Alasan yang mendasari hasil penelitian ini adalah dari 83 perusahaan IPO yang menjadi sampel penelitian ini terdapat 18 perusahaan yang menggunakan penjamin emisi yang bereputasi berdasarkan 20 most active IDX members in total value. Artinya underwriter yang memiliki reputasi akan lebih berani menghadapi risiko dengan menetapkan harga saham IPO yang relatif tinggi karena konsekuensi kualitas penjaminan yang dimilikinya. Reputasi underwriter ini memberikan keyakinan pengambilan keputusan investasi oleh investor dan emiten dalam pelaksanaan penawaran umum perdananya cenderung mengalami tingkat underpricing yang rendah.

\section{Pengaruh Reputasi Auditor Terhadap Underpricing}

Hipotesis kedua pada penelitian ini adalah reputasi auditor berpengaruh negatif terhadap underpricing saham saat IPO. Semakin bereputasi auditor dalam melakukan audit pada laporan keuangan emiten maka semakin rendah tingkat underpricing. Berdasarkan hasil penelitian, diketahui reputasi auditor tidak berpengaruh dengan nilai koefisien bernilai negatif sebesar -172.5510 nilai probabilitas sebesar 0.1731 dan tidak signifikan pada $\alpha 5 \%$. Hal ini berarti reputasi auditor tidak berpengaruh terhadap underpricing, karena nilai prob $>$ 0,05 , yaitu $0.1732>0,05$. Namun hipotesis ini mampu menunjukkan arah hasil penelitian yaitu berpengaruh negatif dengan nilai koefisien -172.5510 . 
Hasil penelitian ini sesuai dengan hasil penelitian Saifudin menggunakan data tahun 2007-2010 di BEI dengan menggunakan metode purpose sampling menunjukkan bahwa reputasi auditor tidak berpengaruh terhadap underpricing. Namun tidak sesuai dengan penelitian yang dilakukan oleh Indra Arifin Djashan (2017) dalam penelitiannya menggunakan data tahun 2009-2010 pada BEI menggunakan sampel sebanyak 68 emiten yang underpricing menyatakan variabel reputasi auditor memiliki pengaruh terhadap underpricing.

Alasan lainnya yang mendukung hasil penelitian ini adalah hal tersebut disebabkan oleh hanya 4 perusahaan dari 83 sampel yang terdaftar berpartner dengan the big four. Artinya reputasi auditor tidak berpengaruh terhadap underpricing. Semakin tinggi reputasi auditor maka tidak mempengaruhi tingkat underpricing dan sebaliknya. Tidak berpengaruhnya reputasi auditor terhadap underpricing disebabkan bahwa investor tidak mempertimbangkan reputasi auditor dalam menilai emiten yang melakukan IPO. Oleh karena itu meskipun emiten menggunakan auditor yang bereputasi tinggi atau bereputasi rendah tidak diperhatikan oleh investor dan dimungkinkan karena kepercayaan investor terhadap hasil laporan dari auditor dalam prospektus rendah, maka para investor tidak memperhatikan auditor mana yang digunakan oleh emiten dalam menilai kelayakan perusahaan dan dalam mengaudit hasil laporan keuangan.

\section{Pengaruh Ukuran Perusahaan Terhadap Underpricing}

Hipotesis ketiga pada penelitian ini adalah ukuran perusahaan berpengaruh negatif terhadap underpricing saham saat IPO. Semakin tinggi nilai ukuran perusahaan yang diketahui oleh calon investor maka akan semakin rendah tingkat underpricing pada saat IPO. Berdasarkan hasil penelitian, diketahui ukuran perusahaan tidak berpengaruh dengan nilai koefisien yaitu -22.75418 nilai probabilitas sebesar 0.1861 dan tidak signifikan pada $\alpha 5 \%$. Hal ini berarti ukuran perusahaan tidak berpengaruh terhadap underpricing, karena nilai prob $>0,05$, yaitu $0.1755>0,05$. Hal tersebut menunjukkan bahwa ukuran perusahaan tidak berpengaruh terhadap tingkat underpricing saham saat IPO. Namun hipotesis ini mampu menunjukkan arah hasil penelitian yaitu berpengaruh negatif dengan nilai koefisien 22.75418 .

Hasil penelitian ini tidak sesuai dengan penelitian yang dilakukan oleh Eka Retnowati (2013) menggunakan data perusahaan IPO pada BEI tahun 2008-2011 dan Reza Widhar Pahlevi (2014) meneliti perusahaan yang melakukan IPO di BEI tahun 2000-2012 menyatakan firm size berpengaruh signifikan terhadap tingkat underpricing. Penelitian Natalia Titik Wijaya (2016) meneliti perusahaan IPO tahun 2008-2012 di BEI menunjukkan bahwa Firm Size secara simultan memiliki berpengaruh terhadap tingkat underpricing.

Alasan yang mendukung hasil penelitian ini adalah dari 83 sampel yang diteliti menunjukkan investor menilai bahwa ukuran perusahaan tidak menjadi faktor utama dalam menentukan keputusan investasi. Pada dasarnya ukuran perusahaan menunjukkan total aset perusahaan, jika nilai ukuran perusahaan tinggi maka semakin besar aset yang bisa dijadikan jaminan perusahaan untuk memperoleh hutang maka ada modal perusahaan untuk meningkatkan kinerja dan laba perusahaan yang otomatis meningkatkan nilai perusahaan. Namun pada penelitian ini dikatakan bahwa ukuran perusahaan tidak berpengaruh terhadap nilai perusahaan dilihat dari hasil penelitiannya yang tidak signifikan. Hal ini dikarenakan investor membeli saham sebuah perusahaan tidak hanya ditinjau dari seberapa besar aktiva perusahaan namun juga dari sisi laporan keuangan, nama baik dan juga kebijakan dividen.

Pada perusahaan yang berukuran besar, manajer akan berusaha memaksimalkan kemampuannya mengelola perusahaan untuk meningkatkan nilai perusahaan, karena pada perusahaan besar cenderung menjadi sorotan masyarakat. Namun pada perusahaan kecil meskipun investasinya kurang besar juga dapat memberikan keuntungan yang optimal. 
Ukuran perusahaan dapat dillihat dari total asetnya, perusahaan dengan total aset yang besar dengan komponen dominan pada piutang dan persediaan belum tentu dapat membayar deviden dikarenakan aset yang menumpuk pada piutang dan persediaan. Perusahaan lebih mempertahankan laba dibandingkan membagikannya sebagai deviden, yang dapat mempengaruhi harga saham dan nilai perusahaan. Mengacu pada temuan tersebut dapat dinyatakan bahwa perusahaan yang memiliki total aset yang besar belum tentu memberikan keyakinan kepada investor dalam mengelola perusahaan agar dapat meningkatkan nilai perusahaan.

\section{SIMPULAN, KETERBATASAN, SARAN Simpulan dan Implikasi}

Penelitian ini bertujuan untuk melihat pengaruh reputasi underwriter, reputasi auditor dan ukuran perusahaan terhadap underpricing pada perusahaan IPO yang terdaftar di Bursa Efek Indonesia (BEI) pada tahun 2014-2018. Penelitian menunjukkan bahwa reputasi underwriter berpengaruh negatif terhadap underpricing, semakin bereputasi underwriter maka akan menghambat tingkat underpricing. Reputasi auditor tidak berpengaruh terhadap underpricing. Reputasi auditor dilihat dari kualifikasi The Big Four tidak dapat menjelaskan tingkat underpricing yang terjadi selama masa amatan. Demikian juga halnya pengaruh ukuran perusahaan, tidak berpengaruh terhadap tingkat underpricing selama masa amatan. Hal ini menunjukkan bahwa besaran total asset perusahaan tidak dapat menjelaskan tingkat underpricing yang terjadi pada perusahaan yang melakukan IPO.

Selain itu, implikasi dari penelitian ini bagi calon emiten yang akan melakukan IPO, penelitian ini menggambarkan bahwa underpricing saham saat IPO menjadi salah satu permasalahan yang dihadapi emiten. Dengan adanya penelitian ini diharapkan membantu calon emiten sebagai bahan pertimbangan sebelum memutuskan untuk menjadikan perusahaan tersebut menjadi perusahaan publik dengan tingkat underpricing saham dapat rendah. Bagi pengembangan ilmu pengetahun, penelitian ini memberikan bukti tambahan mengenai pengaruh reputasi underwriter, reputasi auditor, dan ukuran perusahaan terhadap underpricing serta dampak dengan underpricing saham saat IPO.

\section{Keterbatasan}

Keterbatasan dari penelitian adalah tidak semua perusahaan yang dijadikan sebagai sampel penelitian menyajikan data sesuai dengan kriteria pengambilan sampel penelitian. Dari 144 perusahaan yang terdaftar IPO pada tahun 2014-2018, hanya 83 perusahaan yang ditarik menjadi sampel penelitian. Tahun pengamatan yang digunakan dalam pengambilan sampel hanya untuk 5 tahun data perusahaan IPO dari tahun 2014-2018 yang sebaiknya dapat ditingkatkan ke jumlah tahun dan variabel yang lebih banyak. Hal ini dikarenakan keterbatasan informasi dan keterbatasan data yang tidak lengkap.

\section{Saran}

Bagi peneliti selanjutnya diharapkan dapat 1) Peneliti diharapkan dapat menambahkan variabel-variabel makro ekonomi seperti tingkat suku bunga bank, Indeks Harga Saham Gabungan (IHSG), inflasi, BI rate, dan variabel pendukung lainnya yang berpotensi memengaruhi kondisi pasar saham pada saat IPO. 2) Penelitian selanjutnya diharapkan dapat menganalisis kinerja perusahaan setelah IPO dan performa saham perusahaan yang mengalami underpricing dalam jangka panjang. 3) Penelitian selanjutnya dapat dilakukan dengan memperluas rentang periode penelitian untuk mendapatkan hasil penelitian yang mampu menggambarkan fenomena underpricing dengan lebih baik. 


\section{DAFTAR PUSTAKA}

Abdullah, Nur-Adiana H. and Kamarun N. T. Mohd. (2004). "Factors Influencing The Underpricing of Initial Public Offering in An Emerging Market: Malaysian Evidence". IIUM Journal of Economics and Management. Vol 12 No. 2. Hlm. 1-23.

Ardiansyah, Minsen 2004, "Pengaruh Variabel Keuangan terhadap Awal dan Return 15 Hari Awal dan Return 15 Hari Setelah IPO Serta Moderasi Besaran Perusahaan terhadap Hubungan antara Variabel Keuangan dengan Awal dan Return 15 Hari Awal dan Return 15 Hari Setelah IPO”, Journal Riset Akuntansi Indonesia, Vol.7, No 2

Aggarwal, R., R. Leal and L. Hernandez. 1994. "The Aftermarket Performance of Initial Public Offerings in Latin America". Financial Management, Vol. 22,

Ahmad S. 2018. Analysis of Initial Stock Underpricing Phenomenon at Indonesia. Stock Exchange. Journal Economic and Business of Islam. 3(1): 69-90.

Ajija, Shochrul R et al. 2001. Cara Cerdas Menguasai Eviews. Jakarta: Salemba Empat. Spring, h. 42-53.

Ayuwardani R. 2018. The Influence of Financial and Non-Financial Information to Underpricing Stock Prices when Initial Public Offering (Empirical Study on Go Public Companies on The Indonesia Stock Exchange Period 20112015). Jurnal Nominal. 7(1): 143-158.

Bambang Supomo dan Nur Indriantoro, 2002, Metodologi Penelitian Bisnis, Cetakan Kedua, Yogyakara; Penerbit BFEE UGM.

Beatty, R.P. and J.R. Ritter. 1986. "Investment Banking Reputation and Underpricing of Initial Public Offerings". Journal of Financial Economics, Vol. 15, h. 213-232.

Bursa Efek Indonesia. 2016. Proses Go Public (Go Public Process). Ekonomi. Akses Online : https://gopublic.idx.co.id/. Diakses pada 20 Maret 2020.

Brigham, Eugene F. dan Joel F Houston. 2001. Dasar-dasar Manajemen Keuangan. Jakarta: Salemba Empat.

Eisenhardt, K. M. (1989). Agency theory: An Assesment and Review. The Academy of Management Review, 14(1), 57-74.

(e-Bursa). e-Bursa.com. 2018. Kinerja Saham IPO. Akses Online : https://www.e-bursa.com. Diakses pada 20 Maret 2020.

Fahmi, Irham (2012). “Analisis Kinerja Keuangan”. Alfabeta: Bandung.

Fadila, A., Hamzah, M. Z., dan Sihombing, P. (2015). Determinants factor analysys of underpricing on initial public offering at Indonesia Stock Exchange. Business and Entrepreneurial Review. Vol. 15, No.1, October 2015 page 21 - 32.

Fitriani, Dini. 2011. “ Analisis Faktor-Faktor Yang Mempengaruhi Underpricing Setelah IPO”. Skripsi Akuntansi Fakultas Ekonomi Universitas Diponegoro.

Ghozali, Imam (2016). Aplikasi Analisis Multivariate dengan Program SPSS. Cetakan IV. Badan Penerbit Universitas Diponegoro, Semarang.

Gumanti, Tatang Ari. 2002. "Underpricing dan Biaya-biaya di Sekitar Initial Public Offering”. Wahana, Vol. 5, No. 2.

Hapsari VA. 2012. Analisis Faktor-Faktor yang Mempengaruhi Underpricing Saham pada Penawaran Umum Perdana di BEI Periode 2008-2010 (Studi pada Perusahaan yang Terdaftar di BEI Tahun 2008-2010) [Skripsi]. Semarang (ID): Universitas Diponegoro.

Helen, Sulistio (2005). "Pengaruh Informasi Akuntansi Dan Non Akuntansi Terhadap Initial Return: Studi Pada Perusahaan Yang Melakukan Initial Public Offering Di Bursa Efek Jakarta. Simposium Nasional Akuntansi VIII Solo

Indra, A. Djashan. 2017. Analisis Faktor-Faktor Terhadap Underpricing Saham Perdana. Jurnal Bisnis dan Akuntansi. Vol. 19, No. 2, Desember 2017, 5. 
Jaana Lappalainen, Mervi Niskanen, (2012),"Financial performance os SMEs: impact of ownership structure and board composition", Management Rersearch Review, Vol.35 lss11 pp.1088- 1108

Jin Zhou, Lan-Jun Lao, (2012), “Analaysis of Influencing Factors of IPO Underpricing in ChiNext", Physics rocedia 33 (2012) 846-851

Johnson, J.M. and R.E. Miller. 1988. "Investment Banker Prestige and The Underpricing of Initial Public Offerings". The Journal of Financial Management Association, Vol. 17, No. 2, Summer, h. 19-29.

Jogiyanto. (2010). Teori Portofolio dan Analisis Investasi. Yogyakarta: BPFE UGM

Kaplan, R. S., \& Atkinson, A. A. (1998). Advanced Management Accounting. Upper Saddle River, N.J: Prentice Hall.

Lin, Z., \& Tian, Z. (2012). Accounting conservatism and IPO underpricing: China evidence. Journal of International Accounting, Auditing and Taxation, 21, 127-144.

Loughran, T., \& Ritter, J. (2004). Why has IPO underpricing changed over time?. Financial Management, 33(3), 5-37.

Mayangsari, Sekar. 2003. "Analisis Pengaruh Independensi, Kualitas Audit, serta Mekanisme Corporate Governance terhadap Integritas Laporan Keuangan." Simposium Nasional Akuntansi VI, Surabaya.

Murdiyani. 2009. "Pengaruh Informasi Prospektus Perusahaan Terhadap Initial Return pada Penawaran Saham Perdana (Studi pada Perusahaan LQ-45 2001-2008)". Tesis Dipublikasikan, Fakultas Ekonomika dan Bisnis, Universitas Diponegoro.

Nadia R, Daud RM. 2017. Pengaruh Informasi Keuangan Dan Non Keuangan terhadap Initial Return pada Perusahaan yang melakukan Penawaran Umum Saham Perdana di Bursa Efek Indonesia Periode 2014-2016. Jurnal Ilmiah Mahasiswa Ekonomi Akuntansi. 2(3): 59-72.

Natalia T. Wiyani. 2016. Underpricing Pada Initial Public Offering (Studi Empiris Pada Perusahaan Non Keuangan yang Go Public di Bursa Efek Indonesia Tahun 2011 2014). Jurnal Online Insan Akuntan. Vol.1, No.2 Desember 2016 : 13

Nurgiyantoro, Burhan. 2000. Statistik Terapan Untuk Penelitian-Penelitian Sosial. Penerbit Gadjah Mada University Press. Yogyakarta.

Pahlevi, R.W. 2014. Analisis faktor-faktor yang mempengaruhi tingkat underpricing penawaran umum perdana di BEJ. Jurnal penelitian dan pengembangan akuntansi, Vol. 1 No. 02 Juli $2007: 219-23$

Purbarangga, \& Yuyetta. (2013). Faktor-Faktor yang Mempengaruhi Underpricing Pada Penawaran Umum Saham Perdana. Diponegoro Journal Of Accounting, 1.

Putra, D. G., Rahayu, R., \& Putri, A. (2021). The influence of Enterprise Resource Planning (ERP) Implementation System on Company Performance Mediated by Organizational Capabilities. Journal of Accounting and Investment, 22(2).

Retnowati, Eka. 2013. Penyebab Underpricing pada Penawaran Saham Perdana di Indonesia, Jurnal Akuntansi. 2(2).

Ritter, Jay R. 1998. "Initial Public Offerings". Contemporary Finance Digest, Vol. 2 , No. 1, Spring, h. 5-30.

Risqi, Indita Azisia dan Puji Harto. 2013. "Analisis Faktor-Faktor Yang Mempengaruhi Underpricing Ketika Initial Public Offering (IPO) Di Bursa Efek Indonesia". DIPOnegoro Journal of Accounting. Vol. 2 No. 3.

Rizky, Kharisma, Endang Siti Astuti dan Heru Susilo. 2015. Pengaruh Kemudahan dan Kualitas Informasi Terhadap Minat dan Keputusan Pembelian Secara Online (Survei Pada Konsumen www.ardiansmx.com). Jurnal Administrasi dan Bisnis (JAB).Volume 28.Nomor 1. 
Rock, K. (1986). Why new issues are underpriced. Journal of Financial, 15(1-2), 187-212.

Rosyati dan Arifin Sebeni, Analisis Faktor-Faktor yang Mempengaruhi Underpricing Saham pada Perusahaan Go Public di Bursa Efek Jakarta (Tahun 1997 - 2000), Simposium Nasional Akuntansi V, Semarang, 2002, Hal. 286-297.

Saifudin. 2016. Pengaruh Informasi Akuntansi Dan Non Akuntansi Terhadap Underpricing Ketika Initial Public Offering Di Bursa Efek Indonesia. Jurnal Penelitian Ekonomi dan Bisnis, 1 (1).

Scott, William R. (2000). Financial Accounting Theory. 2nd edition. Toronto, Ont: Prentice Hall Canada Inc.

Su, D., \& Fleisher, B. M. (1999). An empirical investigation of underpricing in Chinese IPOs. Pacific-Basin Finance Journal, 7(2), 173-202.

Sugiyono. (2009). Menggunakan SPSS untuk Statistik Parametrik. Jakarta: PT. Elex Media Komputindo.

Sugiyono, 2006, Statistik Untuk Penelitian, Edisi Pertama, Alfabeta Bandung

Syofyan, R., \& Putra, D.G. (2020, March). The Role of Good Corporate Governance (GCG) Implementation in Indonesian Company. In $4^{\text {th }}$ Padang International Conference on Education, Economics, Business and Accounting (PICEEBA-2 2019) (pp.819-825). Atlantis Press

Tatang et.al. 2015. Determinants of Underpricing in Indonesian Stock Market. Journal of Economics, Business and Management

Triningsih, Sri. 2005. "Analisis dan FaktorFaktor yang Mempengaruhi Tingkat Underpricing Pada Perusahaan yang Go Publik di Bursa Efek Indonesia". Jurnal Akuntansi dan Keuangan, Volume 4. No 2 September 2005, hal. 195-210.

Titman, S. dan R. Wessels. 1988. The Determinants of Capital Structure Choice. The Journal of Finance. Vol. 43. March No. 1.

Wicaksono LS. 2012. Analisis Faktor- Faktor Keuangan yang Mempengaruhi Fenomena Underpricing pada Perusahaan Sektor Keuangan yang Terdaftar di Bursa Efek Indonesia 2002-2010. Berkala Ilmiah Mahasiswa Akuntansi. 1(1): 33-37.

Wardhani, Dwi Erlina. (2003). "Analisis Variabel-variabel yang Mempengaruhi Underpricing dalam Penawaran Saham Perdana (Tahun 1999-2001)". Tesis. Semarang: Universitas Diponegoro.

Winarno, Wing Wahyu. 2009. Analisis Ekonometrika dan statistika dengan Eviews. Yogykarta: UPP STIM YKPN

Yasa, Gerianta Wirawan (2008). "Penyebab Underpricing Pada Penawaran Saham Perdana Di Bursa Efek Jakarta". Jurnal. Denpasar: FE Udayana.

Yolana, C., dan Dwi M. 2005. Variabel Variabel yang Mempengaruhi Fenomena Underpricing pada Penawaran Saham Perdana di BEJ Tahun 1994-2001, Simposium Nasional Akuntansi VIII. Solo. September: 538553. 